\title{
HERITABILITY, REPEATABILITY, AND GENETIC GAINS IN A IMPROVEMENT POPULATION OF CAJUÍZEIRO ${ }^{1}$
}

\author{
Maria Clideana Cabral Maia ${ }^{2 *}$, Adriano da Silva Almeida ${ }^{3}$, Luciano Medina Macedo ${ }^{4}$, Marcos Deon Vilela \\ de Resende ${ }^{5}$, Mairla Nascimento de Lacerda ${ }^{6}$, Lúcio Flavo Lopes Vasconcelos ${ }^{2}$, Luís Cláudio de Oliveira ${ }^{7}$ \\ and Rossana Borges da Silva ${ }^{2}$
}

\footnotetext{
${ }^{1}$ Received on 10.09.2014 accepted for publication on 22.06.2016.

${ }^{2}$ Empresa Brasileira de Pesquisa Agropecuária, Centro de Pesquisa Agropecuária Meio Norte, Teresina, PI - Brasil. E-mail: $<$ clideana.maia@embrapa.br>,<lucio.vasconcelos@embrapa.br> and <rossanaborges2@hotmail.com>.

${ }^{3}$ Universidade Estadual do Piauí, Departamento de Fitotecnia, Parnaíba, PI - Brasil. E-mail: <adrianosalmeida@yahoo.com.br>.

${ }^{4}$ Universidade Federal do Paraná, Departamento de Genética e Melhoramento de Plantas, Curitiba, PR - Brasil. E-mail: <medinacwb@hotmail.com>.

${ }^{5}$ Empresa Brasileira de Pesquisa Agropecuária, Centro Nacional de Pesquisa de Florestas, Colombo, PR - Brasil. E-mail: $<$ marcos.deon@gmail.com>.

${ }^{6}$ Universidade Estadual do Piauí - UESPI, Departamento de Fitotecnia, Graduada em Engenharia Agronômica, Parnaíba, PI - Brasil. E-mail:<mairllaphb@hotmail.com>.

${ }^{7}$ Empresa Brasileira de Pesquisa Agropecuária, Centro de Pesquisa Agroflorestal do Acre, Rio Branco, AC - Brasil. E-mail: $<$ luis.oliveira@embrapa.br>.

*Corresponding author.
}

\begin{abstract}
Cajuí (Anacardium spp) is an endemic fruit trees species in the Northeastern region of Brazil. Thus, this trial aimed to estimate the repeatability coefficients of the agrotechnological variables and to predict the genetic gains of a cajuí improvement population located at the Embrapa Meio-Norte. The data of twelve variables from every crop were evaluated using Selegen-REML/BLUP. The variables were ordered accordingly: V1 fruit mass (FM, in g), V2 peduncle mass (PM, in g), V3 chestnut mass (CM in g), V4 basal diameter (BD in $\mathrm{cm})$, V5 apical diameter (AD in $\mathrm{cm})$, V6 fruit length (FL in $\mathrm{cm}), \mathrm{V} 7$ firmness of endosperm (FIRM, in N), V8 content of vitamin C (PVC in \%), V9 total soluble solids (TSS in \%), V10 pH of endosperm (pH), V11 total titratable acidity (TTA in \%), and V12 relation TSS/TTA (undimensional). The fruit mass and its vitamin $\mathrm{C}$ contents can be estimated from measures of the fruit basal diameter and/or peduncle length, which are easy to be taken and measured experimentally. The medium and high estimates of the repeatability coefficient allowed for the early selection of the genotype 4 with accuracy from the two measures (years). The genotype 4 showed the best prediction means for physical and technological attributes and may be considered a possible candidate for asexual reproduction on crops with double purpose (fresh consumption and industrial).
\end{abstract}

Keywords: Multi-characteristics; Future means; Quantitative genetics.

\section{HERDABILIDADE, REPETIBILIDADE E GANHOS GENÉTICOS EM UMA POPULAÇÃO DE MELHORAMENTO DE CAJUÍZEIRO}

RESUMO-O cajuizeiro (Anacardium spp) é uma das muitas espécies frutiferas arbóreas endêmicas da região Nordeste do Brasil. O objetivo deste trabalho foi estimar os coeficientes de herdabilidade e repetibilidade das variáveis agrotecnológicas e predizer os ganhos genéticos de uma população de melhoramento de cajui da Embrapa Meio Norte. Os dados das variáveis estudadas de cada safra foram avaliados no programa SelegenREML/BLUP. A ordem das variáveis analisadas foi: V1: peso do fruto (PF, em $\mathrm{g}$ ), V2: peso do pedúnculo (PP, em g), V3: peso da castanha (PC, em g), V4: diâmetro basal (DB, em cm), V5: diâmetro apical (DA, em cm), V6: comprimento do fruto (CP, em cm), V7: firmeza do endosperma (FIRMEZA, em N), V8: teor de vitamina C (VitC, em mg/100g), V9: teor de sólidos solúveis totais (SST, em \%), V10: pH do endosperma (pH), V11: acidez total titulável (ATT, em \%) e V12: relação STT/ATT (adimensional). O peso do fruto e teor de 
vitamina C podem ter seus valores preditos a partir do diâmetro basal elou comprimento do pedúnculo cujas medidas são de fácil mensuração. As medianas e altas estimativas dos coeficientes de herdabilidade e repetibilidade possibilitaram selecionar precocemente um dos genótipos, 4, com acurácia a partir de duas medições (anos). O genótipo 4 apresentou as maiores médias para os atributos fisicos e tecnológicos do fruto, podendo ser considerado candidato à seleção para reprodução assexuada no cultivo com objetivo duplo (consumo in natura e industrializado).

Palavras-chave: Multi-características; Médias futuras; Genética quantitativa.

\section{INTRODUCTION}

The cajuí has a small, yellowish or reddish fruit (pseudo-fruit) with a fleshy and juicy pulp. The cajuí peduncle constitutes a good source of dietary fiber, both soluble and insoluble, and, in addition, provides good contents of ascorbic acid and reducing sugars, highlighting also vitamin A and mineral salts such as calcium, iron, and phosphorus (CARNIB et al., 2013).

Despite the great potential for trade and exploitation of the fruits of cajuizeiro in the Northeastern region of Brazil, this species is not domesticated. In their places of occurrence the sale of fruits is a potentially income-generating activity for small and medium farmers (GOMES et al., 2013). However, many farmers are exploiting the fruits extractively, making cajui tree a vulnerable species from the point of view of exploitation of ecosystems (RUFINO et al., 2008).

Before this situation, Embrapa Meio-Norte, for being located in an area of natural occurrence of cajuizeiro, started from 1999 on a collection of land races and studies to characterize the diversity of Anacardium spp, collecting seeds and vegetative material of 11 pre-selected provenances based on productivity and sanityof the plants.

The prediction of genetic values using linear mixed models using BLUP and REML procedures, allows for more accurate estimates of the mean and variance components considering the fixed and random effects, allowing for selection based on free genetic values of the variability portions that results from experimental or environmental factors (DUARTE; VENCOVSKY, 2001; RESENDE, 2004; RESENDE, DUARTE, 2007; PIEPHO et al., 2007). In this context, the mixed model of repeatability considers the correlations between measurements of a particular character for the same individual at different times and, in the case of cajuí, it represents measurements of fruit of genotypes evaluated in different crops, which permits minimizing the temporary effects of the environment.

Revista Árvore, Viçosa-MG, v.40, n.4, p.715-722, 2016
Given the importance for improvement programs, coefficients of quantitative repeatability characters have been estimated in perennial fruit species like mango (COSTA, 2003; MAIA et al, 2014), sweet orange (NEGREIROS et al., 2014.), banana (LESSA et al., 2014), palm heart (BERGO et al., 2013), peach (BRUNA et al., 2012), macaúba (MANFIO etal., 2011), pitanga (DANNER et al., 2010), sour passion fruit (SANTOS et al., 2010).

Selecting agro-technologically superior genotypes should be in advance of the cajuí Embrapa Meio-Norte improvement program. The objective of this study was to estimate the parameters and genetic gains of the agrotechnological variables of a cajuí improvement population of Embrapa Meio-Norte.

\section{MATERIALS AND METHODS}

The working population of the Embrapa MeioNorte improvement program consists of eleven openpollinated progenies collected in areas of natural occurrence of the species in the state of Piaui, and estabilished in an experimental area in the municipality of Parnaiba, PI. Twelve agrotechnological variables were analyzed in 275 fruits of eleven progenies in the first crop, and 175 fruits originated in seven progenies in the second crop due to four genotypes not having produced in the second crop, a total of 25 fruits evaluated by genotype in each crop, following the experimental design in blocks with five repetitions. Only data from the fruits of genotypes in the two crops could be used to estimate the coefficient of repeatability.

The variables were ordered accordingly: V1 fruit mass (FM, in g), V2 peduncle mass (PM, in g), V3 chestnut mass (CM in $\mathrm{g}$ ), V4 basal diameter (BD in $\mathrm{cm}$ ), $\mathrm{V} 5$ apical diameter (AD in $\mathrm{cm}), \mathrm{V} 6$ fruit length $(\mathrm{FL}$ in $\mathrm{cm}), \mathrm{V} 7$ firmness of endosperm (FIRM, in N), V8 content of vitamin C (PVC in \%), V9 total soluble solids (TSS in $\%), \mathrm{V} 10 \mathrm{pH}$ of endosperm $(\mathrm{pH}), \mathrm{V} 11$ total titratable acidity (TTA in \%), and V12 relation TSS/TTA (undimensional). 
Initially, the descriptive statistical analysis of the data, such as correlations between variables, was performed using the Selegen-REML-BLUP software (RESENDE, 2002), for each of the data sets. The main results were the type of distribution observed for each of the variables and their correlations in pairs using Pearson's correlation coefficient (rxy). The variables with asymmetric distribution were transformed using the expression: $\sqrt{x+0,5}$, in order to homogenize the variances and approximate the data to a distribution of the normal type, for further evaluation of their variance components without violating statistical assumptions inherent in this type of analysis. After the transformation of variables with asymmetric distribution, the data for each crop were evaluated in the Selegen-REML-BLUP program (RESENDE, 2002), via model destined for the data evaluation of half-sib progenies in the experimental design of randomized blocks. Later the repeatability model was used for the seven genotypes evaluated in the two crops, using the model for the evaluation of fruits in different crops. The full modeling of the models used is described below.

Mixed linear model (univariate additive model, in randomized blocks)

$\mathrm{y}=\mathrm{Xm}+\mathrm{Za}+\mathrm{Wp}+\mathrm{Qi}+\mathrm{Ts}+\mathrm{e}$, in which:

$\mathrm{y}$ is the data vector.

$m$ is the vector of the effects of the measurementrepetition combinations (assumed to be fixed) added to the general mean.

$\mathrm{a}$ is the vector of the individual genetic additive effects (assumed to be random). $p$ is the vector of the effects of the parcel (random).

$\mathrm{i}$ is the vector of the effects of the genotypes $\mathrm{x}$ measurements interaction (random).

$\mathrm{s}$ is the vector of the permanent effects (random) and $\mathrm{e}$ is the vector of error or residual (random). The upper cases represent the incidence genotypes for the referenced purposes. The vector $\mathrm{m}$ includes all measurements in all repetitions and sets itself simultaneously for the effects of repetitions, measurement, and repetition $\mathrm{x}$ measurement interaction.

\section{RESULTS}

Table 1 shows the correlations between the physical and chemical parameters of fruit: the total mass; peduncle; chestnut; basal diameter; apical diameter; length; firmness; Vitamin-C (mg/100g); Total Soluble Solids - SS ( ${ }^{\circ}$ brix); pH; Acidity (\%); (Total Soluble Solids SS ( ${ }^{\circ}$ brix) / Acidity). The variables fruit mass (V1), peduncle mass (V2), fruit length (V6) and firmness of the endosperm (V7) presented positively asymmetric distribution for the data set of the two crops analyzed and were transformed. The correlations between the main agroindustrial characters are presented subsequently.

The variable fruit mass (FM) showed positive correlations with other physical attributes of the fruit: peduncle mass $(0.99)$, chestnut mass $(0.80)$, basal diameter of the peduncle (0.89), apical diameter of the peduncle (0.71), and peduncle length $(0,90)$ and correlated negatively with the chemical variable total soluble solids $(-0.50)$ (Table 1).

Table 1 - Coefficients of genetic correlation for 12 analyzed variables in fruits from seven progenies in two crops. Tabela 1 -Coeficientes de correlações genéticas para as 12 variáveis analisadas em frutos de sete genótipos em duas safras.

\begin{tabular}{|c|c|c|c|c|c|c|c|c|c|c|c|c|}
\hline Variables & V1 & V2 & V3 & V4 & V5 & V6 & V7 & V8 & V9 & V10 & V11 & V12 \\
\hline V1-PF & - & 0,99* & $\mathbf{0 , 8 0 *}$ & $\mathbf{0 , 8 9} *$ & $\mathbf{0 , 7 1} *$ & $\mathbf{0 , 9 0 *}$ & $-0,19$ & 0,36 & $-0,50 *$ & 0,21 & $-0,13$ & 0,05 \\
\hline V2-PP & & - & $\mathbf{0 , 7 7 *}$ & $\mathbf{0 , 8 8} *$ & $0,69 *$ & $\mathbf{0 , 8 9} *$ & $-0,19$ & 0,33 & $-0,50 *$ & 0,19 & $-0,11$ & 0,03 \\
\hline V3-PC & & & - & $0,81 *$ & $\mathbf{0 , 7 1} *$ & $\mathbf{0 , 7 5} *$ & $-0,08$ & $0,61 *$ & $-0,38$ & 0,32 & $-0,29$ & 0,17 \\
\hline V4-DB & & & & - & $\mathbf{0}, 84^{*}$ & $0,76 *$ & $-0,10$ & $0,49 *$ & $-0,25$ & $0,48 *$ & $-\mathbf{0 , 3 0}$ * & 0,28 \\
\hline V5-DA & & & & & - & $\mathbf{0 , 5 9} *$ & $-0,17$ & $0,58 *$ & $-0,21$ & $0,48 *$ & $-0,17$ & 0,20 \\
\hline V6-CP & & & & & & - & $-0,18$ & 0,25 & $-0,58 *$ & $-0,01$ & $-0,05$ & $-0,07$ \\
\hline V7-FIRMEZA & & & & & & & - & 0,05 & 0,25 & 0,23 & $-0,28$ & 0,34 \\
\hline V8-VitC & & & & & & & & - & 0,16 & $0,49 *$ & $-0,65^{*}$ & $0,65 *$ \\
\hline V9-SST & & & & & & & & & - & $0,52 *$ & $-0,29$ & $0,56 *$ \\
\hline V10-pH & & & & & & & & & & - & $-0,77$ & $\mathbf{0 , 8 4} *$ \\
\hline V11-ATT & & & & & & & & & & & - & $-0,92 *$ \\
\hline V12-STT/ATT & & & & & & & & & & & & - \\
\hline
\end{tabular}

*: Correlation significative at the $5 \%$ level $(\mathrm{p}<0,05)$ highlighted in bold. 
Similarly of the variable fruit mass, the variable peduncle mass and peduncle length presented high phenotypic associations and significant with the variables chestnut mass, basal diameter of the peduncle, apical diameter of the peduncle. As expected, it was negatively correlated with the chemical variable total soluble solids (Table 1).

The attributes chestnut mass, basal and apical diameter of the peduncle were related phenotypically with other physical variables of the fruit and with the chemical variable vitamin $\mathrm{C}$.

Higher concentrations of vitamin $\mathrm{C}$ are found in fruits with higher $\mathrm{pH}(0.49)$, with higher TSS/TTA relation $(0.65)$, which is responsible for the flavor of the fruit and lower acidity $(-0.65)$.

The highest variations of genetic variance were observed for the variables fruit mass (68.37), peduncle mass (59.32), vitamin C (1255.40) and the total soluble solids/acidity relation (65.97) (Table 2 ).

Heritability estimates more than $70 \%$ were found for the variables fruit mass $(0.80)$, peduncle mass $(0.80)$, basal diameter of the peduncle $(0.74)$, peduncle length (0.72), $\mathrm{pH}$ of the fruit (0.92), acidity of the fruit $(0.79)$, and the TSS/TTA relation $(0.92)$.
Heritability medians were obtained for the attributes chestnut mass (0.70), apical diameter of the peduncle (0.32), firmness $(0.33)$, vitamin $\mathrm{C}(0.68)$, and total soluble solids $(0.38)$.

Repeatability values more than $70 \%$ were observed for the variables fruit mass $(0.86)$, peduncle mass (0.86), chestnut mass $(0.80)$, basal diameter of the peduncle $(0.84)$, peduncle length $(0.83)$, vitamin $\mathrm{C}(0.84) \mathrm{pH}$ of the fruit $(0.96)$, acidity of the fruit $(0.85)$ and the TSS/TTA relation (0.96). The estimates repeatability medians were found for the attributes apical diameter of the peduncle (0.63), firmness $(0.50)$, and total soluble solids (0.70).

The ranking, the genetic gain, and the new mean (future mean) of the experimental progenies for the target variables of the selection process are presented in Table 3. Considering the 2010/2011 and $2011 / 2012$ crops, the largest predicted gains per selection were observed for mass of the fruit and of the peduncle, vitamin C, and the TSS/TTA relation.

Genotype 2 was the first in rank for the variables fruit mass and peduncle mass. Progeny 7 stood out for chestnut mass. Genotype 3 was the best for firmness and total soluble solids content. Genotype 4 showed higher genetic gains for the variables vitamin $\mathrm{C}$ and the TSS/TTA relation still setting itself in second in

Table 2 - Components of variance for 12 analyzed variables in two crops.

Tabela 2 -Componentes de variância para as 12 variáveis analisadas emduas safras.

\begin{tabular}{ccccccccc}
\hline $\begin{array}{c}\text { Repeated } \\
\text { Measures }\end{array}$ & Mean & Vg & Vperm & $\mathrm{h}^{2} \mathrm{~g}$ & $\mathrm{c}^{2}$ parc & $\mathrm{c}^{2}$ perm & $\mathrm{r}$ & rgmed \\
\hline V1 & 22,7253 & 68,3679 & 2,4382 & $0,797696+/-0,1350$ & 0,036606 & 0,028448 & $0,862750+/-0,1404$ & 0,971431 \\
V2 & 19,5997 & 59,3170 & 2,1800 & $0,797045+/-0,1350$ & 0,033941 & 0,029292 & $0,860278+/-0,1402$ & 0,972484 \\
V3 & 3,1256 & 0,4613 & 0,0266 & $0,703434+/-0,1268$ & 0,058662 & 0,040587 & $0,802683+/-0,1355$ & 0,952643 \\
V4 & 2,9094 & 0,2075 & 0,0089 & $0,739580+/-0,1300$ & 0,066967 & 0,031822 & $0,838370+/-0,1384$ & 0,955626 \\
V5 & 2,3563 & 0,0475 & 0,0102 & $0,322385+/-0,0858$ & 0,242963 & 0,068953 & $0,634302+/-0,1204$ & 0,781977 \\
V6 & 2,7140 & 0,2072 & 0,0095 & $0,720951+/-0,1284$ & 0,077025 & 0,032932 & $0,830908+/-0,1378$ & 0,950726 \\
V7 & 9,4842 & 2,5755 & 0,8735 & $0,333906+/-0,0874$ & 0,054871 & 0,113246 & $0,502022+/-0,1071$ & 0,881249 \\
V8 & 157,357 & 1255,39 & 56,7809 & $0,676029+/-0,3588$ & 0,128937 & 0,030576 & $0,835542+/-0,3989$ & 0,941307 \\
V9 & 14,0881 & 1,3486 & 0,1963 & $0,383473+/-0,2703$ & 0,258241 & 0,055813 & $0,697527+/-0,3645$ & 0,828780 \\
V10 & 3,5057 & 0,0735 & 0,0005 & $0,919177+/-0,4184$ & 0,036925 & 0,006742 & $0,962844+/-0,4283$ & 0,989037 \\
V11 & 0,8741 & 0,0562 & 0,0022 & $0,789301+/-0,3877$ & 0,032444 & 0,031345 & $0,853090+/-0,4031$ & 0,973448 \\
V12 & 18,1183 & 65,9656 & 0,4743 & $0,922019+/-0,4191$ & 0,034932 & 0,006629 & $0,963580+/-0,4284$ & 0,989374 \\
\hline
\end{tabular}

In which: the Variance components (Individual REML):

Vg: genotypical variance between progenies; equivalent to $(1 / 4)$ of the additive genetical variance.

Vperm: variance of the permanent effects.

$\mathrm{h}^{2} \mathrm{~g}=\mathrm{h}^{2}$ individual heritability between progenies

r: individual repeatability.

$\mathrm{c}^{2}$ parc $=\mathrm{c}^{2}$ : coefficient of determination of the parcel effects.

$\mathrm{c}^{2}$ perm $=$ coefficient of determination of the permanent effects

rgmed: genotypical correlation through measures.

Mean: it is the general mean of the experiment. 
Table 3 - Components of means (individual BLUP) obtained in the experiment by level-selecting progenies, for fruit mass - FM and chestnut mass - CM and agro-technological variables (pulp content - PP, fruit hardness, vitamin C, total soluble solids content - TSS, acidity (TTA), and the relation TSS/TTA).

Tabela 3 - Componentes de médias (BLUP individual) obtidos dentro do experimento através da seleção em nível de genótipos, para caracteres peso do fruto - PF e peso da castanha - PC e variáveis agrotecnológicas (teor de polpa$P P$, Firmeza, vitamina $C$, teor de sólidos solúveis totais - SS, acidez e relação SS/ATT).

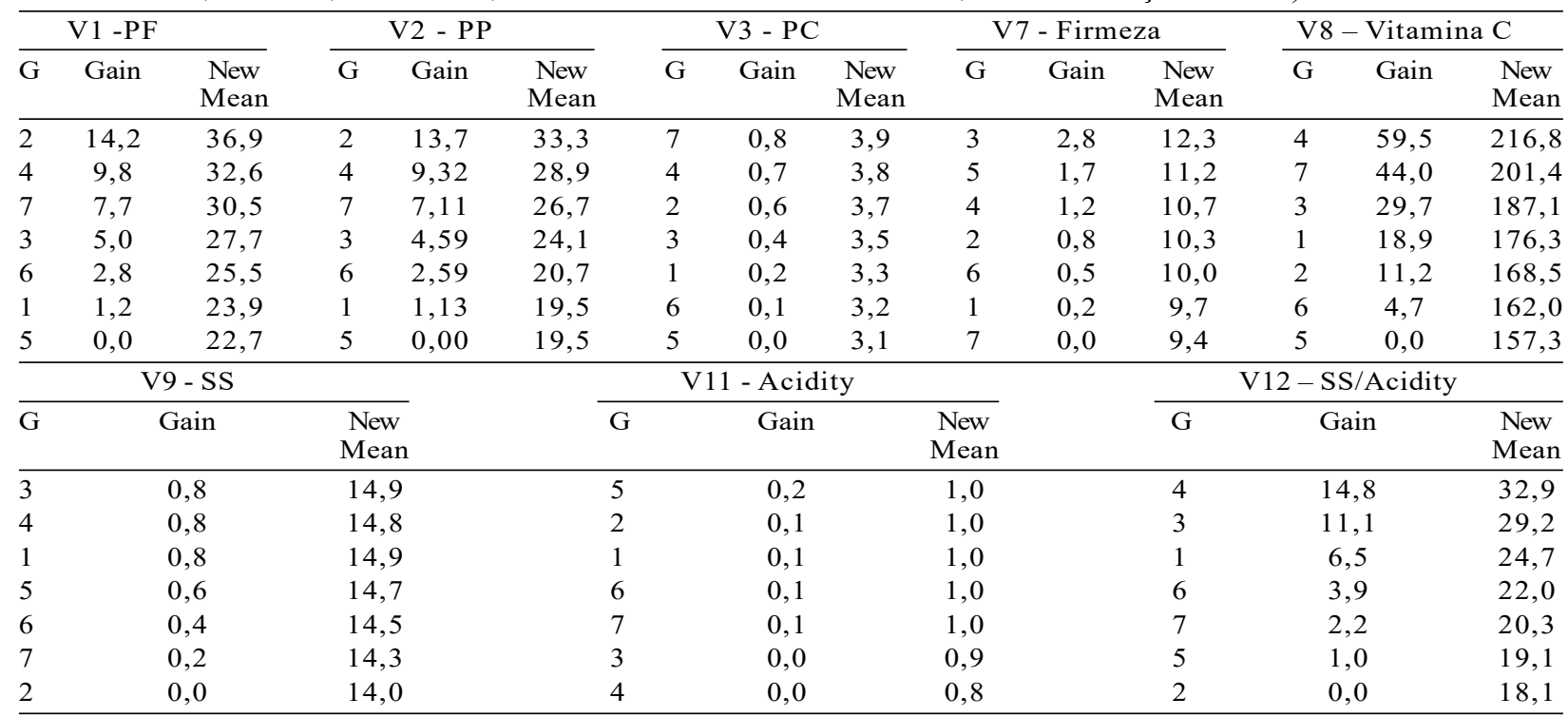

G: Genotype

the ranking for fruit mass, peduncle mass, chestnut mass, and total soluble solids in addition to having less acidity. Rarely, it is possible to summarize in a single individual all the features to register for the use as fresh fruit and for processing simultaneously.

\section{DISCUSSION}

As expected, fruit mass showed significant genetic correlation (Table 1) with all the physical variables of the fruit, indicating common genetic control among them: fruit mass and peduncle mass (0.99), fruit mass and chestnut mass (0.80), fruit mass and basal (0.89) and apical (0.71) diameter and fruit mass and peduncle length $(0.90)$ which are the primary components of production. In turn, the technological variable vitamin $\mathrm{C}(0.36)$ being negatively correlated with the total soluble solids attribute - SS (-0.49). Thus, the fruit mass and vitamin $\mathrm{C}$ content can be take its measure predicted from the basal diameter and/or peduncle length (Table 1).

The variable firmness of the fruit showed a positive genetic correlation with the attribute: TSS/TTA (0.34), in which it is inferred that fruits that taste better are also the ones with highest postharvest longevity, with this property being quite interesting for the marketing of fruit for fresh consumption, that is, for utilization of the fresh fruit (peduncle). According to Moura et al. (2013), when the correlation is positive and has a high magnitude, the characters may be considered a single unit selection. In turn, unfavorable correlations generally hinder the simultaneous selection of the top characters in improvement programs.

The variable vitamin $\mathrm{C}$ is found in higher concentrations in larger fruit, since it has strong correlation with the physical characteristics of the fruits: vitamin $\mathrm{C}$ and fruit mass (0.36), Vitamin $\mathrm{C}$ and peduncle mass (0.33) vitamin $C$ and chestnut mass $(0,61)$, vitamin $\mathrm{C}$ and basal diameter (0.49), vitamin $\mathrm{C}$ and apical diameter (0.58).

One difficulty in the improvement program can be seen through the strong and negative genetic correlation between total soluble solids (TSS) and fruit mass (-0.50), TSS and peduncle mass (-0.50), TSS and chestnut mass (-0.38), TSS and peduncle length (-0.58), which infers that the smaller fruits have the highest

Revista Árvore, Viçosa-MG, v.40, n.4, p.715-722, 2016

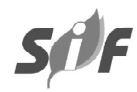


total soluble solids ( ${ }^{\circ}$ Brix). In addition, the TSS attribute was positively correlated with $\mathrm{pH}(0.52)$ and the TSS/ TTA relation (0.56).

Like the TSS variable, the TSS/TTA relation hinders indirect selection due to it not being correlated with the physical variables (easily measured). This variable has only correlations with the variables: TSS/TTA and firmness (0.34), TSS/TTA and vitamin C (0.65),TSS/ TTA and TSS (0.56) and $\mathrm{pH}(0.84)$ and negative correlation with TTA (-0.92).

If the repeatability estimate is high, the selection based on only one or a few observations will be effective, and if the value of the estimate is low, the mean of several observations must be used to achieve the same selection efficiency (LUSH, 1964; TURNER; YOUNG, 1969).

The obtained repeatability estimates (Table 2) varied, generally from medians to high, these results corroborate those obtained in other native perennial species for the attributes yield of fruits per raceme $(0.60)$ and number of rachilles per raceme $(0.80)$ in bacabi (Oenocarpus mapora) (OLIVEIRA; MOURA, 2010), for the variables acidity (0.95) and total soluble solids $(0.94)$ in bacuri (Platonia insignis Mart) (SILVA et al., 2009) and for fruit production (0.56) in açaí (FARIAS NETO et al., 2011).

The median and high estimates of the repeatability coefficient imply facility for the improver to identify and select promising genetic materials with accuracy from few measurements, suggesting a high regularity in the repetition of these variables from one cycle to another to achieve high reliability in obtained means and good genetic control.

The coefficients of the permanent effects for most of the variables presented low magnitude $(<0.07)$, revealing that the permanent environmental variation from one year to another was not important. The variation of the permanent environment was relevant to the attributes firmness (0.11).

The coefficient of determination due to the common environment of the parcel quantifies the variability within the blocks, in which the high value of this coefficient means high environmental variability within the parcels (ROCHA et al., 2007). In general, the coefficients for determining the effects of parcels were low $(<0.08)$, determining small environmental effect between parcels, except for the variables apical diameter (0.2429), vitamin C (0.1289), and TSS (0.2582).

The low influence of stochastic environmental effects and high genetic control estimates in the transmission of the attributes for the next generation were found through the high individual heritability values in the narrow sense for dimensional variables of the fruits and chemical variables. Showing therefore great prospects for success in the selection process of main characters involved in the productivity and quality of the fruits of this population.

In consonance with the high heritability observed for a considerable portion of important attributes for the genetic improvement of the population studied and for the effectiveness of the improvement of this population, the highest genetic variabilities were observed for fruit mass (68.3679), peduncle mass (59.3170), vitamin C (1255.3977), and the SS/Acidity relation (65.9656). These variables are important in the selection process for the genetic improvement of this population consisting in the primary components of the production and fruit quality attributes. For Moura et al. (2013), a wide phenotypic variability for fruit characters, can be prioritized, in the future, in a conservation and genetic improvement program of this species. The genetic improvement of all species is highly dependent on the genetic resources held in germplasm banks and/or reserves in situ of the species.

Genotype 4 showed the highest mean future for attributes mass of the fruit, peduncle, and chestnut; firmness, vitamin C, TSS, and the TSS/TTA relation, besides lower acidity, being able to be considered a candidate for selection for asexual reproduction, aiming the exploitation of the genetic variability (additive and dominant and the epistatics), on crops with dual purpose, that is, for fresh consumption and products derived from the process of fruit processing (Table 3 ).

Genotypes 2, 7, and 3 had future or predicted means better that the means of the population in this environmental condition for the characters fruit mass and peduncle mass, chestnut mass, firmness, TSS, and the TSS/TTA relation, respectively, being pre-selected as genitors to form a controlled breeding system to obtain the population of first recurrent selection cycle, aiming to gather in one or few homogeneous genotypes elites improved for cloning, presented, simultaneously, characters of agrotechnological interest. 


\section{CONCLUSIONS}

The medium and high estimates of coefficients of heritability and repeatability of physical and chemical variables allowed for early selection of genotype 4 with accuracy from two measurements (years), registered as a candidate for selection for fresh consumption and for processing.

Genotype 4 stood out with the highest future means for the attributes (fruit, peduncle, and chestnut mass, firmness, vitamin $\mathrm{C}, \mathrm{SS}$, and TSS/TTA relation, beside the lowest acidity being able to be considered a candidate for selection for asexual reproduction.

Embrapa Meio-Norte's cajuí improvement program can advance with the second recurrent selection cycle or promote a study of adaptability and stability with the genotypes candidates for selection.

\section{REFERENCES}

BERGO, C.L.; NEGREIROS, J.R.S.; MIQUELONI, D.P.; LUNZ, A.M.P. Estimativas de repetibilidade de caracteres de produção em pupunheiras para palmito da raça putumayo. Revista Brasileira de Fruticultura, v.35, p.829-836, 2013.

BRUNA, E.D.; MORETO, A.L.; DALBÓ, M.A. Uso do coeficiente de repetibilidade na seleção de clones de pessegueiro para o Litoral Sul de Santa Catariana. Revista Brasileira de Fruticultura, v.34, p.206-215, 2012.

CARNIB, L. P. A.; AGUIAR, A. O.; OLIVEIRA, B. B. R.; MOREIRA-ARAÚJO, R. S. R.

Características físico-químicas, conteúdo de nutrientes e fenólicos totais no cajuí (Anacardium humile). Nutrile, v.38. Suplemento, p.206-206, 2013.

COSTA, J.G. Estimativas de repetibilidade de alguns caracteres de produção em mangueira. Ciência Rural, v.33, n.2, p.263-266, 2003.

DANNER, M.A.; RASEIRA, M.C.B.; SASSO, S.A.Z.; CITADIN, I.; SCARIOT, S. Repetibilidade de caracteres de fruto em araçazeiro e pitangueira. Ciência Rural, v.40, p.2086-2091, 2010 .

DUARTE, J.B.; VENCOVSKY, R. Estimação e predição por modelo linear misto com ênfase na ordenação de médias de tratamentos genéticos. Sciencia Agrícola, v.58, n.1, p.109-117, 2001.

GOMES, S. O.; SOUZA, V. A. B.; COSTA, M. P. S. D.; SILVA, C. C. P.; VALE, E. M.; SOUSA, M.; SOUZA, J. P. B. Avaliação da qualidade físico e química de cajuí (Anacardium spp.) na região Meio-Norte. Geintec, v.3, n.3, p.139-145, 2013.

FARIAS NETO, J.T.; RESENDE, M.D.V.; OLIVEIRA, M.S.P. Seleção simultânea em progênies de açaizeiro irrigado para produção e peso do fruto. Revista Brasileira de Fruticultura, (Impresso), v.33, p.532-539, 2011.

LESSA, L.S.; LEDO, C.A.S.; AMORIN, E.P.; SILVA, S.O. Estimativa de repetibilidade de híbrido diploides (AA) de bananeira. Pesquisa Agropecuária Brasileira, v.49, p.109-117, 2014.

LUSH, J.L. Melhoramento dos animais domésticos. Rio de Janeiro: Cedegra, 1964. 570p.

MAIA, M.C.C.; RESENDE, M.D.V.; OLIVEIRA, L.C.; VASCONCELOS, L.F.L.; LIMANETO, F.P. Análise genética em genótipos de manga rosa via REML/BLUP. Revista Agrotecnologia, v.5, n. 1, p.01-16, 2014.

MANFIO, C.E.; MOTOIKE, S.Y.; SANTOS, C.E.M.; PIMENTEL, L.D.; QUEIROZ, V.; SATO, A.Y.

Repetibilidade em características biométricas do fruto de macaúba. Ciência Rural, v.41, p.70-76, 2011.

MOURA, N.F.; CHAVES, L.J.; NAVES, R.V. Caracterização física de frutos de pequizeiro (Caryocar brasiliense Camb) do cerrado. Revista Árvore [online]. v.37, n.5, p.905-912, 2013.

NEGREIROS, J.R.S.; ANDRADE NETO, R.C.; MIQUELONI, D.P.; LESSA, L.S. Estimativa de repetibilidade para caracteres de qualidade de frutos de laranjeira doce. Pesquisa

Agropecuária Brasileira, v.49, p.40-48, 2014.

OLIVEIRA, M.S.P.; MOURA, E.F. Repetibilidade e número mínimo de medições para caracteres de cacho de bacabi (Oenocarpus mapora). Revista Brasileira de Fruticultura, v.32, n.4, p.1173-1179, 2010.

Revista Árvore, Viçosa-MG, v.40, n.4, p.715-722, 2016 
PIEPHO, H. P.; MÖHRING, J.; MELCHINGER, A. E.; BÜCHSE, A. BLUP for phenotypic selection in plant breeding and variety testing. Euphytica, v.161, p.209-228, 2007.

RESENDE, M.D.V. Software SELEGEN - REML/ BLUP. Colombo: Embrapa Florestas, 2002.67p. (Documentos, 77).

RESENDE, M.D.V. Métodos estatísticos ótimos na análise de experimentos de campo. Colombo: Embrapa Florestas, 2004. 65p. (Documento, 100).

RESENDE, M.D.V.; DUARTE, J.B. Precisão e controle de qualidade em experimentos de avaliação de cultivares. Pesquisa Agropecuária Tropical, v.37, p.182-194, 2007.

ROCHA, M. G. B.; PIRES, I. E.; ROCHA, R. B.; XAVIER, A. CRUZ, C. D. Seleção de genitores de Eucalyptus grandis e de Eucalyptus urophylla para produção de híbridos interespecíficos utilizando REML/BLUP e informação de divergência genética. Revista
Árvore [online]., v.31, n.6, p.977-987, 2007.

RUFINO, M. S. M.; CORRÊA, M. P. F.; ALVES, R. E.; LEITE, L. A. S.; SANTOS, F. J. S. Utilização atual do cajuí nativo da vegetação litorânea do Piauí, Brasil. Interamerican Society for Tropical Horticulture, v.52, p.147-159, 2008.

SANTOS, C. E. M.; BRUCKNER, C. H.; CRUZ, C. D.; SIQUEIRA, D. L.; PIMENTEL, L. D.; ROSADO, L. D. S. Repetibilidade em características do fruto do maracujazeiro. Revista Ceres, Viçosa, v. 57, n.3, p. 343-350, 2010 .

SILVA, R. G.; CHAVES, M. C. L.; ARNHOLD, E.; CRUZ, C. D. Repetibilidade e correlações fenotípicas de caracteres do fruto de bacuri no Estado do Maranhão bacuri no Estado do Maranhão. Acta Scientiarum Agronomy, v.31, n.4, p.587-591, 2009.

TURNER, H.N.; YOUNG, S.S.Y. Quantitative genetics in sheep breeding. New York: Cornell University, 1969. 332p. 